\title{
Summer Picnics
}

Ellen Zhang, BA

Neurology ${ }^{\circledR}$ 2022;98:324. doi:10.1212/WNL.0000000000013110

We picked out decorations, mother and baby ducks

adorning the yellow nursery.

When you came home, you latched onto my breast, burped, slept, pooped, cried. Gave home a new meaning.

You learned to say "mama" first, and I cried. When you learned to walk, we took you to Boston Commons to bask in the branching, green hours.

Ducks quacking to life before your eyes, wide as buttons on your green coat, matching hat. Here, five years ago, we fell in love. Pronouns widening, loving you deeper by the day.

In August, we worried and memorized developmental milestones. In those frayed moments, there was no fair way to distribute pain, ease guilt, unravel complex diagnostic labels.
Correspondence

Dr. Zhang

ellen_zhang@

hms.harvard.edu
The first year of Rett's, we gained a label only to worry more about loss of talking, walking, growing, and even breathing. Silence replacing speech, sirens replaced counting sheep, seizures replaced sleep.

We memorized your favorite stuffed animals, movies you loved, and stories reminding you that you were safe.

Your resilience made us proud, progress made us hope, and time made us stronger together.

We count things in moments, remember certainties. Like how we still go to the pond, the ripples of water, not unlike your waves into our lives. Together, we throw bread at ducks. Relish our time in the soft, turning hours. 


\title{
Neurology
}

\author{
Summer Picnics \\ Ellen Zhang \\ Neurology 2022;98;324 Published Online before print November 22, 2021 \\ DOI 10.1212/WNL.0000000000013110
}

This information is current as of November 22, 2021

Updated Information \& Services

Subspecialty Collections

Permissions \& Licensing

Reprints including high resolution figures, can be found at: http://n.neurology.org/content/98/8/324.full

This article, along with others on similar topics, appears in the following collection(s):

All Epilepsy/Seizures

http://n.neurology.org/cgi/collection/all_epilepsy_seizures

All Pediatric

http://n.neurology.org/cgi/collection/all_pediatric

Rett Syndrome

http://n.neurology.org/cgi/collection/rett_syndrome

Information about reproducing this article in parts (figures,tables) or in its entirety can be found online at:

http://www.neurology.org/about/about_the_journal\#permissions

Information about ordering reprints can be found online:

http://n.neurology.org/subscribers/advertise

Neurology ${ }^{\circledR}$ is the official journal of the American Academy of Neurology. Published continuously since 1951, it is now a weekly with 48 issues per year. Copyright (C 2021 American Academy of Neurology. All rights reserved. Print ISSN: 0028-3878. Online ISSN: 1526-632X.

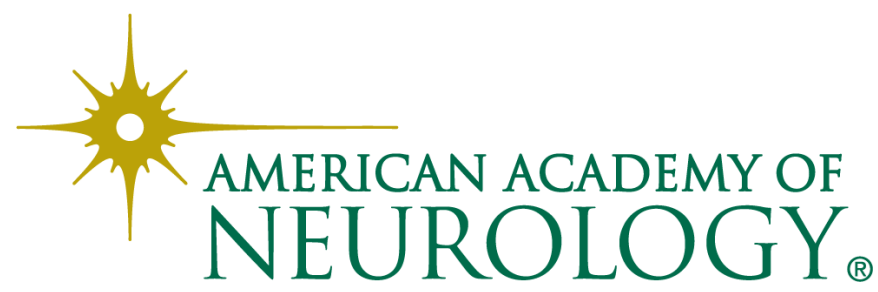

